\title{
Anti-infective and cytotoxic properties of Bupleurum marginatum
}

\author{
Mohamed L Ashour ${ }^{1,2}$, Mahmoud Z El-Readi ${ }^{1,3}$, Razan Hamoud ${ }^{1}$, Safaa Y Eid ${ }^{1}$, Sherweit H El Ahmady², \\ Endalkachew Nibret ${ }^{1}$, Florian Herrmann ${ }^{1}$, Mahmoud Youns ${ }^{4,5}$, Ahmed Tahrani ${ }^{1}$, Dorothea Kaufmann ${ }^{1}$ \\ and Michael Wink ${ }^{1 *}$
}

\begin{abstract}
Background: Bupleurum marginatum Wall. ex DC (Apiaceae) is a perennial herb widely used in traditional Chinese and Kampo medicine for the treatment of various infectious diseases. The biological activities of B. marginatum have not been fully investigated. This study aims to investigate the antitrypanosomal, antimicrobial and antiviral activities of methanol (ME) and dichloromethane (DCM) extracts of B. marginatum aerial parts and the ability of both extracts to inhibit the growth of different cancer cell lines.

Methods: Phytochemical characterization of the extracts was performed by LC-MS profiling. The antitrypanosomal activity was evaluated using the resazurin method. The antimicrobial activity was assessed using agar diffusion and microdilution methods, and the minimum inhibitory concentration (MIC) values were determined. The antiviral activity was determined for $6.25,12.5$, and $50 \mu \mathrm{g} / \mathrm{mL}$ doses using a plaque reduction assay. Cytotoxicity was investigated in eight cancer cell lines (Caco-2, CCL-81, CCRF-CEM, COS-7, HL-60, MIA PaCa-2, MCF-7, and PANC-1) using the MTT assay and the caspase 3/7 activity was determined over the range of $62.5-1000 \mu \mathrm{g} / \mathrm{mL}$.

Results: Phytochemical analyses resulted in the characterization of 15 components, mainly flavonoids and lignans. The DCM extract showed significant antitrypanosomal activity $\left(I_{50}: 36.21 \mu \mathrm{g} / \mathrm{mL}\right)$ and moderate activity against Streptococcus pyogenes (MIC value: $0.25 \mathrm{mg} / \mathrm{mL}$ ). At a dose of $12.5 \mu \mathrm{g} / \mathrm{mL}$, the DCM extract inhibited $73.6 \%$ of the plaque production by hepatitis A virus. CCRF-CEM cells were the most sensitive to both extracts $\left(I_{50}: 12.5-22.7 \mu \mathrm{g} / \mathrm{mL}\right)$. The cytotoxicity was mediated by induction of apoptosis (19-fold increase in the cellular caspase 3/7 level after treatment with the DCM extract at $1 \mathrm{mg} / \mathrm{mL}$ ).
\end{abstract}

Conclusions: ME and DCM extract of B. marginatum showed anti-infective and antiproliferative effects.

\section{Introduction}

Plants have been the foundation of traditional medicinal systems in many countries for hundreds of years to prevent or treat ailments and health disorders. Despite the tremendous success in manufacturing synthetic, semisynthetic therapeutic agents or both, approximately $80 \%$ of the world population still relies on herbal medicines for their health care [1].

The family Apiaceae comprises more than 3500 species, of which 300 are medicinally active and have been used in folk medicine [2]. Among the Apiaceae genera, Bupleurum encompasses about 180-190 species [3].

\footnotetext{
* Correspondence: wink@uni-hd.de

${ }^{1}$ Institute of Pharmacy and Molecular Biotechnology, Heidelberg University,

Im Neuenheimer Feld 364, 69120 Heidelberg, Germany

Full list of author information is available at the end of the article
}

Bupleurum marginatum Wall. ex DC is a perennial herb of up to $60 \mathrm{~cm}$ in height, with oblanceolate leaves and yellow umbel flowers, and used in Chinese medicine [4].

B. marginatum has been widely used in Europe, China, Korea, and Japan in the form of herbal teas, either alone or in combination with other ingredients, for treatment of the common cold and inflammation [5,6]. In addition, it is employed to treat hepatitis, cancer, microbial infections, and fever associated with malaria [7-9].

The secondary metabolites of B. marginatum have been investigated previously, and various classes of compounds were identified. Specifically, saikosaponins were found in small amounts [10], while flavonoid glycosides and aglycones such as rutin, narcissin, isoquercetrin, isorhamnetin, and quercetin were commonly found in the plant [11]. In addition, lignans such as marginatoxin [11-13] and many

\section{Biomed Central}


phytosterols (stigmasterol, $\alpha$-spinasterol, $\beta$-sitosterol, and daucosterol) have been described from both the aerial and subterranean parts $[6,12]$.

Our previous work in 2009 [14] investigated the antibacterial, antifungal, antioxidant, anti-inflammatory and cytotoxic activity of the essential oil from the B. marginatum aerial parts. To our knowledge, the biological activities of different extracts from $B$. marginatum have not been studied in detail.

This study aims to investigate the antitrypanosomal, antimicrobial and antiviral activities of methanol (ME) and dichloromethane (DCM) extracts of B. marginatum aerial parts and the ability of both extracts to inhibit the growth of different cancer cell lines.

\section{Methods}

\section{Plant materials}

The aerial parts of $B$. marginatum were kindly provided by Prof. Thomas Efferth (University of Mainz, Mainz, Germany). The identity of the plant was ascertained by one of the authors (MA) in our laboratory by DNA barcoding and confirmed morphologically at the Botanical Garden, Heidelberg University (Heidelberg, Germany). Voucher specimens of the plant material were deposited at the Department of Biology, Institute of Pharmacy and Molecular Biotechnology, Heidelberg University under accession number IPMB P7367.

\section{Chemicals}

Chemicals were purchased from AppliChem ${ }^{\bullet}$ (Darmstadt, Germany), Fluka ${ }^{\oplus}$ (Buchs, Switzerland), and Sigma ${ }^{\oplus}$ (Sternheim, Germany). The solvents used were of analytical grade unless otherwise mentioned, and were purchased from Merck $^{\circledR}$ (Darmstadt, Germany), J.T. Backer ${ }^{\circledR}$ (Deventer, Netherlands), and Theo Seulberger ${ }^{\bullet}$ (Karlsruhe, Germany). Media and supplements for cell cultures were obtained from Gibco ${ }^{\circ}$ (Invitrogen, Karlsruhe, Germany) and Greiner Labortechnik $^{\oplus}$ (Frickenhausen, Germany).

\section{Preparation of ME and DCM extracts}

The ME and DCM extracts were prepared by refluxing $100 \mathrm{~g}$ of finely milled, air-dried aerial parts of B. marginatum with $1.5 \mathrm{~L}$ of methanol or dichloromethane, respectively, for $6 \mathrm{~h}$. The extracts were filtered, dried by passage over anhydrous sodium sulfate, and evaporated to dryness under reduced pressure at $40^{\circ} \mathrm{C}$ in a Büchi rotavapor R200 with B-172 Büchi vacuum system (Büchi Labortechnik, Flawil, Switzerland). The dried extracts were stored at $4^{\circ} \mathrm{C}$ in the dark until analysis.

\section{General experimental procedures LC-MS profiling of the extracts}

The LC-ESI-MS system used consisted of a Merck Hitachi ${ }^{\circledR}$ HPLC system (Hitachi Ltd., Tokyo, Japan) composed of a binary L-6200A intelligent pump, an ERC-3215 $\alpha$ degasser (ERC Inc., Saitama, Japan), a rheodyne injector with a 20- $\mu$ l loop, and a LiChroCART RP-18, endcapped (5 $\mu \mathrm{m})$, $250 \times 4 \mathrm{~mm}$ i.d. column (Merck, Darmstadt, Germany) coupled with a Micromass VG Quattro II mass spectrometer (Waters, Manchester, United Kingdom). The ESIMS system was operated using Waters MassLynx 4.0 software as described in our previous work [15]. The mobile phase was a linear gradient of $100 \%$ water (containing $0.5 \%$ formic acid) to $50 \%$ acetonitrile at a flow rate of $1 \mathrm{~mL} / \mathrm{min}$ over $60 \mathrm{~min}$, followed by a linear gradient to $100 \%$ acetonitrile over $10 \mathrm{~min}$. Mass spectrometric detection of phenolics was performed in both the positive and negative ion modes over the range of $400-1400 \mathrm{~m} / z$ by $\mathrm{N}_{2}$ as a nebulizer gas and a source temperature of $120^{\circ} \mathrm{C}$. The chromatograms were processed by Waters MassLynx ${ }^{\oplus} 4.0$ software (Waters Corporation, Milford, MA , USA).

\section{Biological activities Antitrypanosomal activity}

Mature bloodstream forms of Trypanosoma brucei brucei TC221, the causative agent of Nagana (which can be used as a model for human sleeping sickness), were grown in Baltz medium supplemented with $20 \%$ inactivated fetal bovine serum and $1 \%$ penicillin-streptomycin. The cells were incubated in a humidified atmosphere containing $5 \% \mathrm{CO}_{2}$ at $37^{\circ} \mathrm{C}$.

Trypanocidal activity was determined by resazurin as a cell proliferation indicator dye as previously described [16]. The extracts were serially diluted with medium in a two-fold manner to attain final concentrations in the range of 250 to $3.9 \mu \mathrm{g} / \mathrm{mL}$ in 96 -well Plates. T. b. brucei was seeded into 96-well plates at a density of $1 \times 10^{4}$ cells/well in $100 \mu \mathrm{L}$ of medium. The cells were then incubated with various concentrations $(3.9-250 \mu \mathrm{g} / \mathrm{ml})$ of the test samples for $24 \mathrm{~h}$. Ten microliters of resazurin was added to each well and incubated for a further $24 \mathrm{~h}$. The absorbance of the wells was recorded by a Tecan ${ }^{\circ}$ plate reader (Männedorf, Switzerland) at dual wavelengths of 492 and $595 \mathrm{~nm}$, and the $\mathrm{IC}_{50}$ was calculated [17].

Each sample concentration was tested in triplicate, and the experiments were repeated independently twice. The maximum concentration of the solvent (DMSO) did not exceed $1.25 \%$ in the medium that contained the highest concentration of each test sample. Diminazene aceturate was used as a positive control ( $\left.\mathrm{IC}_{50}: 0.088 \mu \mathrm{g} / \mathrm{mL}\right)$ [18].

\section{Antimicrobial activity}

Microbial strains The antimicrobial activity was evaluated by standard strains. The Gram-positive bacteria examined included Bacillus subtilis (ATCC 6051), Staphylococcus aureus (ATCC 29213), Staphylococcus epidermidis (ATCC 14990), Streptococcus pyogenes (ATCC 12344), Streptococcus agalactiae (ATCC 27956), and Methicillin-Resistant 
Staphylococcus aureus (MRSA; NTCC 10442). The Gramnegative bacteria Escherichia coli (ATCC 25922) and Pseudomonas aeruginosa (ATCC 27853) were also included, as well as the fungi Candida albicans (ATCC 90028) and Candida glabrata (ATCC MYA 2950). Multiresistant clinical isolates from patients, such as MRSA 818014 and MRSA 818081, were also examined. All microorganisms were supplied by Medical Microbiology Laboratory, Hygiene Institute, Heidelberg University.

Inocula preparation Prior to the test, bacterial and fungal cultures were prepared as follows. The bacterial cultures were subcultured in Columbia medium with $5 \%$ sheep blood (BD, Heidelberg, Germany) and incubated at $37^{\circ} \mathrm{C}$ for $24 \mathrm{~h}$, while the fungal cultures were subcultured in $\mathrm{CHROMagar}^{\oplus}$ Candida (BD, Heidelberg, Germany) and incubated at $25^{\circ} \mathrm{C}$ for $48 \mathrm{~h}$.

Agar diffusion method Suspensions of microorganisms were prepared in a saline solution and adjusted with 0.5 McFarland Standard to a final concentration of approximately $1 \times 10^{6} \mathrm{CFU} / \mathrm{mL}$ as previously reported [14]. Mueller Hinton agar (Biomerieux, Marcy l'Étoile, France) was inoculated with the pathogens. Wells with a diameter of $6 \mathrm{~mm}$ were cut out by a Pasteur pipette and loaded with $40 \mu \mathrm{L}$ of $3.2 \mathrm{mg} / \mathrm{mL}$ extracts. DMSO, ampicillin, vancomycin, and nystatin were used as controls. The diameters of the growth inhibition zones were measured in triplicate after incubation at $37^{\circ} \mathrm{C}$ for $24 \mathrm{~h}$ (bacteria) or $48 \mathrm{~h}$ (fungi).

Determination of minimum inhibitory concentration (MIC) and minimum microbicidal concentration (MMC) values The MIC was determined by the broth microdilution method [19]. Various sample concentrations (0.05$25 \mu \mathrm{g} / \mathrm{mL}$ ) were dissolved in 5\% DMSO and placed in a 96-well plate (Greiner Bio-one, Frickenhausen, Germany). The final count of the microbial suspension in Mueller Hinton broth (Fluka, Buchs, Switzerland) and Sabouraud Dextrose broth (Oxoid, Hampshire, UK) was adjusted to approximately $5 \times 10^{5} \mathrm{CFU} / \mathrm{mL}$ for bacteria and fungi, respectively. The plates were incubated at $37^{\circ} \mathrm{C}$ for $24 \mathrm{~h}$ (bacteria) or $48 \mathrm{~h}$ (fungi)., The suspension $(3 \mu \mathrm{L})$ from each incubated well was spread out on medium and incubated at $37^{\circ} \mathrm{C}$ for $24 \mathrm{~h}$ (bacteria) or $48 \mathrm{~h}$ (fungi) to determine the MMC. The MMC was defined as the lowest concentration of each extract that completely killed the microorganisms. Each test was performed in duplicate. The antibiotics ampicillin, vancomycin, and nystatin were used as positive controls.

\section{Antiviral activity}

Antiviral activity was determined by a plaque reduction assay [20]. Briefly, a confluent layer of Vero cells (CCL81) was obtained by culturing the cells for $24 \mathrm{~h}$ in $0.5 \%$
$\mathrm{CO}_{2}$ at $37^{\circ} \mathrm{C}$. The cells were inoculated, separately with herpes simplex virus type-1 (HSV-1), hepatitis A virus (HAV), or vesicular stomatitis virus (VSV) $\left(1 \times 10^{-1}-\right.$ $1 \times 10^{-7} / \mathrm{ml}$ ) and incubated at $37^{\circ} \mathrm{C}$ for $1 \mathrm{~h}$. The infected cell cultures $\left(2 \times 10^{3} \mathrm{PFU}\right)$ were washed and overlaid with DMEM containing three concentrations of each extract $(6.25,12.5$, and $50 \mathrm{ig} / \mathrm{mL})$ for $1 \mathrm{~h}$ at room temperature. Each concentration was tested in three replicates, and the cultures were overlaid with nutrient agarose $(2 \times \mathrm{DMEM} / 1.8 \%$ agarose $[\mathrm{v} / \mathrm{v}])$ containing $25 \mathrm{mM}$ $\mathrm{MgCl}_{2}$. After $72 \mathrm{~h}$ of incubation, the cells were fixed with $10 \%$ formaldehyde in phosphate-buffer solution $(\mathrm{pH} 7.3$ ) for $1 \mathrm{~h}$ and stained with $0.5 \%$ crystal violet in $20 \%$ ethanol. The plaques were counted, and the percentage of viral inhibition was calculated as $[1-\mathrm{fV} d / \mathrm{V} c)] \times 100$, where $\mathrm{V} d$ and $V c$ are the numbers of plaques in the presence and absence of the test samples, respectively. Acyclovir was employed as a positive control.

\section{Cytotoxicity \\ Cell cultures}

Human MCF-7 (breast cancer), PANC-1 (pancreatic carcinoma), MIA PaCa-2 (pancreatic cancer), Caco-2 (colon cancer), and African green monkey kidney COS-7 (fibroblast-like epithelium) and CCL-81 (Vero) cell lines were maintained in DMEM complete medium (L-glutamine supplemented with $10 \%$ heat-inactivated fetal bovine serum, $100 \mathrm{U} / \mathrm{mL}$ penicillin, and $100 \mathrm{U} / \mathrm{mL}$ streptomycin), with addition of $1 \mathrm{mM}$ sodium pyruvate and $10 \mathrm{mM}$ nonessential amino acids for culture of Caco-2 cells. Human CCRF-CEM (leukemia) and HL-60 (myeloid) cells were maintained in RPMI complete medium. The cells were maintained at $37^{\circ} \mathrm{C}$ in a humidified atmosphere containing $5 \% \mathrm{CO}_{2}$. All experiments were performed with cells in the logarithmic growth phase.

\section{Cytotoxicity and cell proliferation assay}

Cytotoxicity was determined in triplicate using the MTT cell viability assay [21]. Exponentially growing cells of each cell line were seeded in 96-well plates (Greiner Labortechnik $^{\oplus}$, Frickenhausen, Germany) at $2 \times 10^{4}$ cells/well. The cells were cultured for $24 \mathrm{~h}$, and then incubated with various concentrations of the extracts ranging from 1 to $1000 \mu \mathrm{g} / \mathrm{mL}$ at $37^{\circ} \mathrm{C}$ for $24 \mathrm{~h}$. Subsequently, the cells were incubated with $0.5 \mathrm{mg} / \mathrm{mL}$ MTT for $4 \mathrm{~h}$. The formed formazan crystals were dissolved in $200 \mu \mathrm{L}$ of DMSO. The absorbance was detected at $570 \mathrm{~nm}$ by a Tecan ${ }^{\oplus}$ Safire II Reader (Männedorf, Switzerland). The cell viability (percentage) of three independent experiments was calculated as follows:

$$
\begin{aligned}
\text { Cell viability }(\%)= & (\text { OD of treated cells }) / \\
& (\text { OD of control cells }) \times 100 \% .
\end{aligned}
$$


The cytotoxic agent doxorubicin was used as a positive control.

\section{Apoptosis assay}

The Caspase-Glo ${ }^{\mathrm{Tm}}$ 3/7 Assay (Promega ${ }^{\circledR}$, Mannheim, Germany) was used to detect caspase 3/7 activities in MIA PaCa-2 cells after treatment with each type of extract (62.5 to $1000 \mu \mathrm{g} / \mathrm{mL}$ ). This test provides a proluminescent caspase $3 / 7$ substrate, which contains the caspase 3-specific tetrapeptide sequence DEVD in a reagent mix, and is optimized for cell lysis and determination of caspase activities. Cells cultured in DMEM were seeded in 96-well plates and treated with the extracts $(62.5 \mu \mathrm{g}$ to $1 \mathrm{mg}$ ). Subsequently, $100 \mu \mathrm{L}$ of caspase $3 / 7$ reagent was added to the wells after 6 or $24 \mathrm{~h}$ of treatment, mixed, and incubated at room temperature for $30 \mathrm{~min}$ [22]. The luminescence was measured by a Mithras LB 940 instrument (Berthold Technologies, Bad Wildbad, Germany). Cellular apoptosis was expressed as the fold change relative to the untreated control in three independent experiments.

\section{Data analysis}

All biological experiments were repeated at least three times. Data were presented as the mean \pm standard deviation (SD). The $\mathrm{IC}_{50}$ was determined as the drug concentration that resulted in a $50 \%$ reduction in cell viability or inhibition of biological activity. The $\mathrm{IC}_{50}$ values were calculated by a four parameter logistic curve (SigmaPlot ${ }^{\circ}$ 11.0, Systat Software Inc., San Jose CA, USA). The significance of differences in data between the groups was determined by one-way analysis of variance followed by the Tukey test for equality of variances using SPSS $^{\circ} 11.0$ (SPSS Inc., Chicago, USA). Differences were considered statistically significant at $P<0.05$.

\section{Results and discussion}

HPLC profiling and chemical compositions of the extracts The chromatographic profiles were established by HPLC/ MS (Figure 1). The ME extract (Figure 1A) revealed the presence of high contents of flavonoids, and to lesser extents lignans, sterols, and triterpenoid saponins, as previously reported by the authors [11]. The DCM extract (Figure 1B) showed a similar pattern of secondary metabolites with higher yields of lignans and terpenoids compared with those detected in the ME extract. These results are in accordance with our previously detected terpenoids in the $n$-hexane extract [14].

In the B. marginatum ME and DCM extracts, the following compounds (Figure 2) were identified unequivocally: quercetin and its glycosides rutin and isoquercetrin; isorhamnetin and its glycoside narcissin; (3,4-dimethoxybenzyl)-2-(3,4-methylenedioxybenzyl) butyrolactone; and marginatoxin. In addition, sterols such as $\beta$-sitosterol and $\alpha$-spinasterol and their glucosides, daucosterol, stigmasterol, 7-stigmasten-3-ol, 7-stigmast-7,25-dien-3-ol, and hexadecanol were either isolated or identified from the different extracts.

\section{Activity against $T$. b. brucei}

The trypanocidal activities of both extracts were illustrated in Figure 3. The ME and DCM extracts showed moderate activities with $\mathrm{IC}_{50}$ values of $104.80 \pm 5.11(P=$ $0.0027)$ and $36.21 \pm 2.68(P=0.0014) \mu \mathrm{g} / \mathrm{mL}$, respectively. The selectivity indexes of the two extracts were calculated as 2.3 and 2.9, respectively, indicating low selectivity against trypanosomes compared with their cytotoxicity toward HL-60 cells.

Based on previous work [23,24], many flavonoid aglycones exhibitantitrypanosomal activity in both in vitro and in vivo models. However, the activity of most flavonoids against $T$. b. brucei and the selectivity of these compounds were related to the presence of a free phenolic $\mathrm{OH}$ group in position 6 which can dissociate to a phenolate ion under physiological conditions [23]. Thus, it is probable that the activity of the extracts could be related to the presence of several flavonoids that could interact together in synergistic or even additive manners [25].

To our knowledge, few studies have addressed the antitrypanosomal activity of lignans [26]. However, two closely structurally related lignans, justicidin B and piscatorin, which were isolated from the aerial parts of Phyllanthus piscatorum Kunth (Euphorbiaceae), exhibited strong activity against the bloodstream forms of Trypanosoma brucei rhodesiense with $\mathrm{IC}_{50}$ values of 0.55 and $6.1 \mu \mathrm{M}$, respectively [27].

\section{Antimicrobial activity}

The antimicrobial activity of the ME and DCM extracts was assessed by the agar diffusion and microdilution methods, and the MIC and MMC values were determined (Tables 1 and 2). In general, both extracts showed growth inhibition of standard Gram-positive and Gram-negative bacteria in the diffusion assay. However, no inhibition zones could be detected for the two fungi and the resistant pathogenic isolates.

All of the tested Gram-positive bacteria were susceptible to the ME and DCM extracts with MIC values ranging from 0.25 to $4 \mathrm{mg} / \mathrm{mL}$. S. agalactiae and B. subtilis were sensitive to both extracts with similar MIC values of $0.5 \mathrm{mg} / \mathrm{mL}$. S. pyogenes was the most susceptible to the DCM extract with an MIC value of $0.25 \mathrm{mg} / \mathrm{mL}$. The Gram-negative pathogens and fungi were less sensitive, and their MIC values were $\geq 2 \mathrm{mg} / \mathrm{mL}$. The two extracts did not differ significantly in their antimicrobial actions for all of the susceptible microorganisms. However, they were significantly different from both ampicillin and 


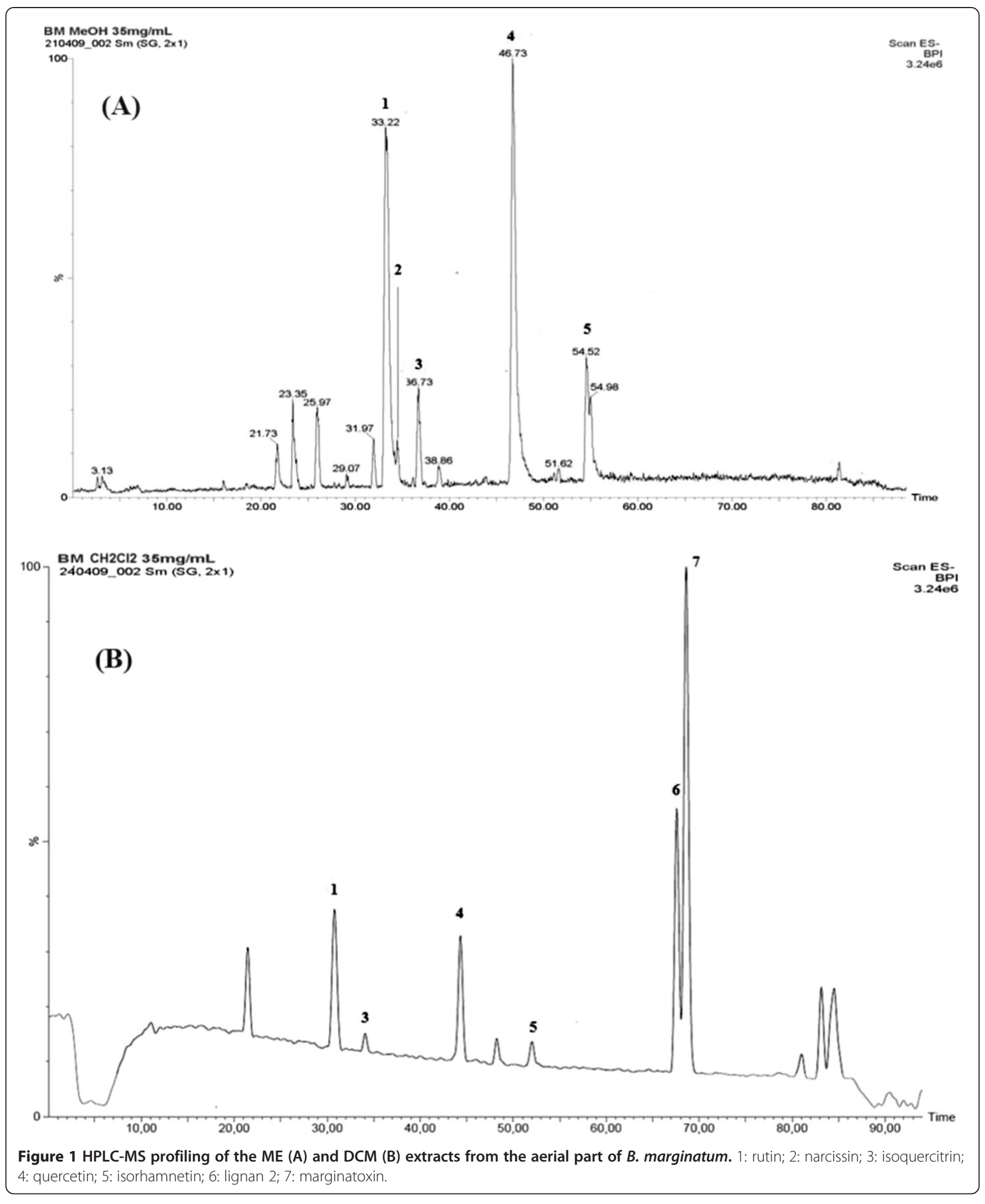


<smiles>COc1cc2c(c(OC)c1OC)C(c1ccc3c(c1)OCO3)C1C(=O)OCC1C2</smiles><smiles>CCOc1cc(-c2oc3cc(O)cc(O)c3c(=O)c2OCCO)ccc1O</smiles>

\begin{tabular}{|c|c|c|}
\hline & $\mathbf{R}_{1}$ & $\mathbf{R}_{2}$ \\
\hline Rutin & $\mathrm{H}$ & $\alpha$-L-rha- $(1 \bullet 6)-\beta$-D-glu \\
\hline Isoquercetrin & $\mathrm{H}$ & $\beta$-D-glucose \\
\hline Quercetin & $\mathrm{H}$ & $\mathrm{H}$ \\
\hline Isorhamntin & $\mathrm{CH}_{3}$ & $\mathrm{H}$ \\
\hline Narcissin & $\mathrm{CH}_{3}$ & $\alpha$-L-rha- $(1 \bullet 6)-\beta$-D-glu \\
\hline
\end{tabular}
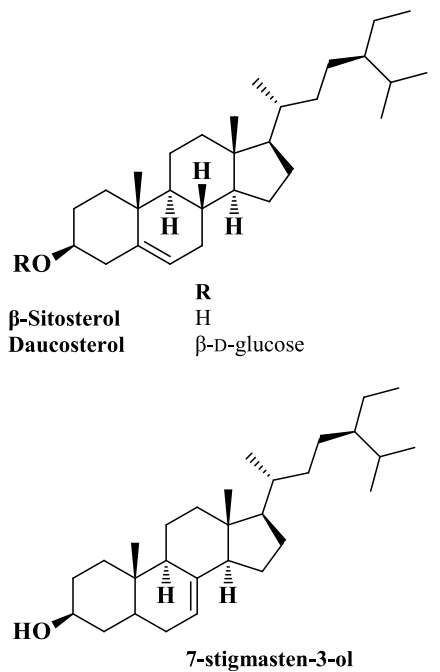<smiles>COc1ccc(CC2COC(=O)C2Cc2ccc3c(c2)OCO3)cc1OC</smiles>

(3,4-dimethoxybenzyl)-2-(3,4-methylenedioxybenzyl) butyrolactone (lignan 2)
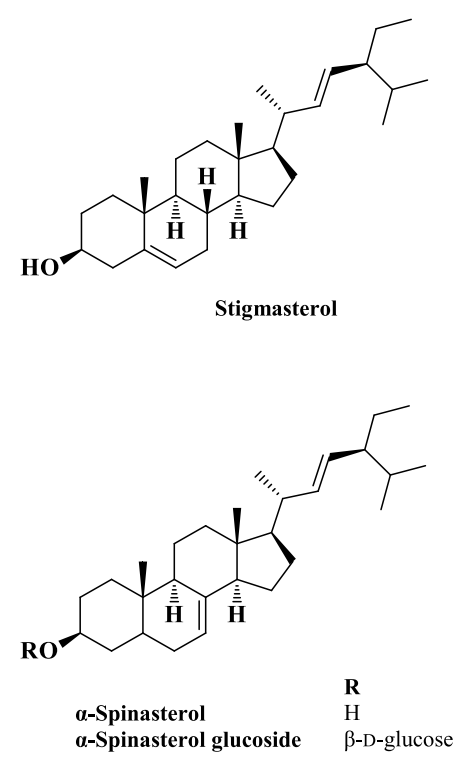

Figure 2 Structures of the isolated compounds from the aerial part of $B$. marginatum.

vancomycin as seen from the difference in inhibition zones in Table 1.

Although it was expected that the ME extract of B. marginatum would possess superior activity compared with the DCM extract based on the richness and diversity of secondary metabolites, our findings did not reveal a significant difference. The expected higher activity of the ME extract was related to the presence of saikosaponins, which function as detergents and mostly exist in their mono-desmosidic forms [28]. These compounds can intercalate via their lipophilic moiety with the lipophilic membrane bilayer of the pathogens after forming a complex with cholesterol, while the hydrophilic sugar part remains outside of the cell and interacts with glycoproteins or glycolipids [28]. A loss of the membrane integrity

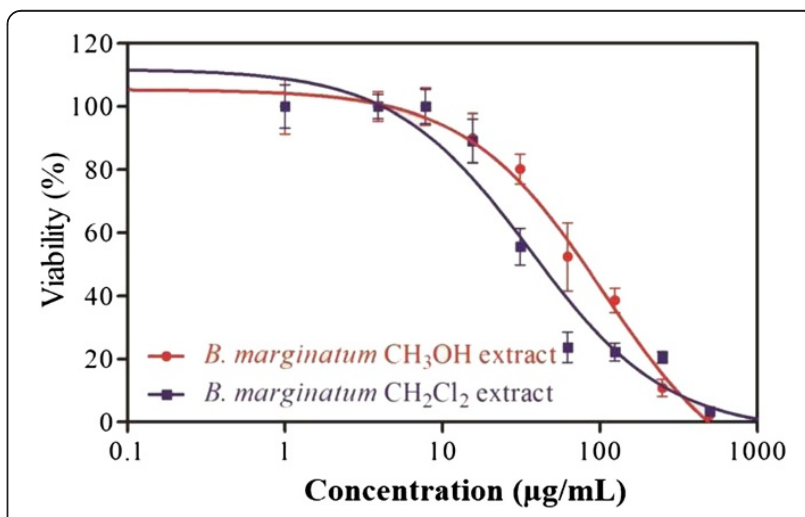

Figure 3 Dose-dependent growth inhibition of $T . b$. brucei (resazurin assay). 
Table 1 Mean inhibition zones of the B. marginatum extracts against different pathogens determined by the agar diffusion method

\begin{tabular}{|c|c|c|c|c|c|}
\hline \multirow[t]{2}{*}{ Microorganisms } & \multicolumn{5}{|c|}{ Diameter of inhibition zone $(\mathrm{mm})$} \\
\hline & $\begin{array}{c}\mathrm{CH}_{3} \mathrm{OH} \text { extract } \\
640 \mu \mathrm{g} / \text { well }\end{array}$ & $\begin{array}{c}\mathrm{CH}_{2} \mathrm{Cl}_{2} \text { extract } \\
640 \mu \mathrm{g} / \text { well }\end{array}$ & $\begin{array}{l}\text { Ampicillin } \\
10 \mu g / \text { well }\end{array}$ & $\begin{array}{c}\text { Vancomycin } \\
10 \mu \mathrm{g} / \text { well }\end{array}$ & $\begin{array}{c}\text { Nystatin } \\
10 \mu \mathrm{g} / \text { well }\end{array}$ \\
\hline \multicolumn{6}{|l|}{ Gram positive } \\
\hline MRSA 818014 & $\mathrm{NI}$ & $\mathrm{NI}$ & $5.3 \pm 0.3$ & $10.3 \pm 0.7$ & NT \\
\hline MRSA 818081 & $\mathrm{NI}$ & $\mathrm{NI}$ & $7.2 \pm 0.0$ & $10.6 \pm 1.3$ & NT \\
\hline MRSA NCTC 10442 & $\mathrm{NI}$ & $\mathrm{Nl}$ & $\mathrm{NI}$ & $10.0 \pm 0.2$ & NT \\
\hline Staphylococcus aureus ATCC 29213 & $4.3 \pm 0.7\left(P^{* 1,2}=0.001,0.008\right)$ & $5.1 \pm 1.4\left(P^{1,2}=0.001,0.008\right)$ & $24.0 \pm 1.5$ & $10.7 \pm 1.6$ & NT \\
\hline Staphylococcus epidermidis ATCC 14990 & $4.3 \pm 2.5\left(P^{* 1,2}=0.016,0.027\right)$ & $5.6 \pm 1.3\left(P^{1,2}=0.021,0.019\right)$ & $12.2 \pm 1.7$ & $10.0 \pm 0.5$ & NT \\
\hline Streptococcus pyogenes ATCC 12344 & $5.7 \pm 1.6\left(P^{* 1,2}=0.006,0.021\right)$ & $7.2 \pm 2.1\left(P^{1,2}=0.011,0.017\right)$ & $25.0 \pm 1.2$ & $15.3 \pm 1.6$ & NT \\
\hline Streptococcus agalactiae ATCC 27956 & $5.2 \pm 1.1\left(P^{* 1,2}=0.024,0.021\right)$ & $5.2 \pm 1.5\left(P^{1,2}=0.023,0.021\right)$ & $17.1 \pm 1.5$ & $12.0 \pm 1.7$ & NT \\
\hline Bacillus subtilis ATCC 6051 & $\mathrm{Nl}$ & $4.2 \pm 2.1\left(P^{1,2}=0.012,0.038\right)$ & $12.7 \pm 0.5$ & $8.7 \pm 1.2$ & NT \\
\hline \multicolumn{6}{|l|}{ Gram negative } \\
\hline Pseudomonas aeruginosa ATCC 27853 & $4.1 \pm 0.0$ & $5.3 \pm 1.3$ & $\mathrm{NI}$ & $\mathrm{Nl}$ & NT \\
\hline Escherichia coli ATCC 25922 & $4.3 \pm 0.2$ & $\mathrm{Nl}$ & $5.4 \pm 1.2$ & $\mathrm{Nl}$ & NT \\
\hline \multicolumn{6}{|l|}{ Fungi } \\
\hline Candida albicans ATCC 90028 & $\mathrm{Nl}$ & $\mathrm{Nl}$ & NT & NT & $10.0 \pm 1.2$ \\
\hline Candida glabrata ATCC MYA 2950 & $\mathrm{NI}$ & $\mathrm{Nl}$ & NT & NT & $12.1 \pm 1.2$ \\
\hline
\end{tabular}

Data are presented as means $\pm S D(n=3)$.

NI: no inhibition zone; NT: not tested.

$P^{1,2}$ : Significant differences relative to ampicillin and vancomycin, respectively.

Table 2 Minimum inhibitory concentrations (MICs) and minimum microbicidal concentrations (MMCs) of the B. marginatum extracts against different pathogens determined by the broth microdilution method

\begin{tabular}{|c|c|c|c|c|c|c|c|c|c|c|}
\hline \multirow[t]{2}{*}{ Microorganisms } & \multicolumn{2}{|c|}{$\begin{array}{c}\mathrm{CH}_{3} \mathrm{OH} \text { extract } \\
\mathrm{mg} / \mathrm{mL}\end{array}$} & \multicolumn{2}{|c|}{$\begin{array}{c}\mathrm{CH}_{2} \mathrm{Cl}_{2} \text { extract } \\
\mathrm{mg} / \mathrm{mL}\end{array}$} & \multicolumn{2}{|c|}{$\begin{array}{l}\text { Ampicillin } \\
\mu \mathrm{g} / \mathrm{mL}\end{array}$} & \multicolumn{2}{|c|}{$\begin{array}{c}\text { Vancomycin } \\
\mu \mathrm{g} / \mathrm{mL}\end{array}$} & \multicolumn{2}{|c|}{$\begin{array}{c}\text { Nystatin } \\
\mu \mathrm{g} / \mathrm{mL}\end{array}$} \\
\hline & MIC & MMC & MIC & MMC & MIC & MMC & MIC & MMC & MIC & MMC \\
\hline \multicolumn{11}{|l|}{ Gram positive } \\
\hline MRSA 818014 & 4 & $>4$ & 4 & $>4$ & 6.2 & 6.2 & 0.8 & 0.8 & NT & NT \\
\hline MRSA 818081 & 4 & $>4$ & 4 & $>4$ & 6.2 & 50 & 0.8 & 0.8 & NT & NT \\
\hline MRSA NCTC 10442 & 4 & $>4$ & 4 & $>4$ & 6.2 & 12.5 & 0.8 & 1.6 & NT & NT \\
\hline Staphylococcus aureus ATCC 29213 & 4 & $>4$ & 4 & $>4$ & 0.4 & 3.1 & 0.4 & 0.8 & NT & NT \\
\hline Staphylococcus epidermidis ATCC 14990 & 2 & $>4$ & 2 & $>4$ & 0.4 & 0.8 & 0.8 & 1.6 & NT & NT \\
\hline Streptococcus pyogenes ATCC 12344 & 0.5 & 4 & 0.25 & 0.75 & 0.1 & 0.1 & 0.1 & 0.2 & NT & NT \\
\hline Streptococcus agalactiae ATCC 27956 & 0.5 & 4 & 0.5 & 4 & 0.1 & 0.2 & 0.4 & 0.4 & NT & NT \\
\hline Bacillus subtilis ATCC 6051 & 0.5 & 2 & 0.5 & 1 & 0.1 & 0.8 & 0.2 & 0.8 & NT & NT \\
\hline \multicolumn{11}{|l|}{ Gram negative } \\
\hline Pseudomonas aeruginosa ATCC 27853 & 4 & $>4$ & 4 & $>4$ & $\mathrm{NI}$ & $\mathrm{NI}$ & $\mathrm{Nl}$ & $\mathrm{NI}$ & NT & NT \\
\hline Escherichia coli ATCC 25922 & 2 & 4 & 4 & $>4$ & 6.2 & 12.5 & $\mathrm{Nl}$ & $\mathrm{NI}$ & NT & NT \\
\hline \multicolumn{11}{|l|}{ Fungi } \\
\hline Candida albicans ATCC 90028 & $\mathrm{NI}$ & NT & $\mathrm{Nl}$ & NT & NT & NT & NT & NT & 1.6 & 1.6 \\
\hline Candida glabrata ATCC MYA 2950 & $\mathrm{NI}$ & NT & $\mathrm{Nl}$ & NT & NT & NT & NT & NT & 1.6 & 1.6 \\
\hline
\end{tabular}

NI: no inhibition; NT: not tested. 
Table 3 Effects of the B. marginatum extracts on viral replication using direct plaque reduction assays

\begin{tabular}{lcrr}
\hline & & \% inhibition in viral replication & VSV \\
\cline { 2 - 4 } $\mathrm{CH}_{3}$ OH extract & HSV-1 & HAV & $12.87 \pm 1.88$ \\
$6.25 \mu \mathrm{g} / \mathrm{mL}$ & $21.75 \pm 1.18$ & $33.71 \pm 1.82$ & $41.37 \pm 2.16$ \\
$12.50 \mu \mathrm{g} / \mathrm{mL}$ & $56.44 \pm 1.60$ & $65.01 \pm 2.12$ & $56.59 \pm 2.03\left(P^{*}=0.0024\right)^{\mathrm{c}}$ \\
$50.00 \mu \mathrm{g} / \mathrm{mL}$ & $66.26 \pm 2.72\left(P^{*}=0.0011\right)^{\mathrm{a}}$ & $76.56 \pm 4.29\left(P^{*}=0.025\right)^{\mathrm{b}}$ & $39.27 \pm 1.95$ \\
$\mathrm{CH}_{2} \mathrm{Cl}_{2} \mathrm{extract}$ & & & $69.55 \pm 3.16$ \\
$6.25 \mu \mathrm{g} / \mathrm{mL}$ & $29.45 \pm 1.23$ & $42.51 \pm 2.21$ & $73.67 \pm 3.03$ \\
$12.50 \mu \mathrm{g} / \mathrm{mL}$ & $59.53 \pm 3.41$ & $81.42 \pm 6.15\left(P^{*}=0.019\right)^{\mathrm{b}}$ & $79.96 \pm 4.51\left(P^{*}=0.0009\right)^{\mathrm{c}}$ \\
$50.00 \mu \mathrm{g} / \mathrm{mL}$ & $73.91 \pm 4.13\left(P^{*}=0.0017\right)^{\mathrm{a}}$ & & \\
\hline
\end{tabular}

Data are presented as means $\pm S D(n=3)$.

HSV-1: herpes simplex virus type-1; HAV: hepatitis A virus; VSV: vesicular stomatitis virus.

$P^{*}$ : Significant difference relative to acyclovir.

${ }^{\text {a }}$ Significant difference at $P=0.048$.

${ }^{\mathrm{b}}$ Significant different at $P=0.037$.

'Significant difference at $P=0.001$.

allows other highly polar flavonoid glycosides to penetrate the pathogen and exert their effects. On this basis, the antimicrobial activity is likely to be influenced by the synergistic and additive effects of all components [28].

\section{Antiviral activity}

The ME and DCM extracts showed promising antiviral activity at a dose of $50 \mu \mathrm{g} / \mathrm{mL}$. HAV was the most sensitive, showing $76.6 \%$ and $81.4 \%$ inhibition of viral replication with the ME and DCM extracts, respectively (Table 3). The antiviral activity of the different Bupleurum species have been related to the contents of saikosaponins, which exert powerful and selective antiviral activity [29-31]. However, the DCM extract with a low steroid content showed a higher activity than the ME extract against the three viruses, which might be attributed to its high contents of lignans and flavonoid aglycones.

Several modes of cytotoxic and antiviral activity were associated with lignans, including tubulin binding, reverse transcriptase, and topoisomerase inhibition [32,33]. However, the most relevant mechanism associated with lignans involved binding to tubulin, disruption of the cellular cytoskeleton and spindle apparatus of the infected host cells, and interfering with some critical viral processes [32]. Marginatoxin, isolated from a B. marginatum extract, showed high structural similarity with podophyllotoxin, which was previously reported to show potent activity against HSV-1, measles virus, VSV, and many other viruses [34-36].

In addition, flavonoids constitute the largest group of secondary metabolites with antiviral activity in the entire plant kingdom. The several phenolic groups in the flavonoid skeleton, which can dissociate into phenolate ions and form hydrogen and ionic bonds with amino acid residues of proteins, facilitates the antiviral activity by inhibiting viral polymerase activity and binding with viral nucleic acid or viral capsid proteins, leading to a reduction in viral replication $[37,38]$. Most flavonoids, including quercetin and rutin, show promising activity against HSV-I, HIV-1, HIV-2, poliovirus type 1, parainfluenza virus type 3 , and respiratory syncytial virus [39-41].

Table 4 Cytotoxicities of the B. marginatum extracts ( $\left(C_{50}\right.$ values; $\left.\mu \mathrm{g} / \mathrm{ml}\right)$ after $24 \mathrm{~h}$ of incubation

\begin{tabular}{lcll}
\hline Cell lines & Methanol extract $(\boldsymbol{\mu g} / \mathbf{m L})$ & Dichloromethane extract $(\boldsymbol{\mu g} / \mathbf{m L})$ & $P^{\mathbf{1}}$ value \\
\hline Caco-2 & $108.44 \pm 11.43\left(P^{*}=0.012\right)$ & $56.81 \pm 6.30\left(P^{*}=0.009\right)$ & 0.0011 \\
CCRF-CEM & $22.75 \pm 2.76\left(P^{*}=0.014\right)$ & $12.54 \pm 1.87\left(P^{*}=0.004\right)$ & 0.0335 \\
CCL-81 & $307.51 \pm 13.76\left(P^{*}=0.007\right)$ & $72.81 \pm 6.15\left(P^{*}=0.013\right)$ & 0.0016 \\
COS-7 & $576.0 \pm 11.65\left(P^{*}=0.009\right)$ & $67.40 \pm 2.76\left(P^{*}=0.021\right)$ & 0.0019 \\
HL-60 & $100.88 \pm 4.02\left(P^{*}=0.021\right)$ & $35.07 \pm 2.28\left(P^{*}=0.007\right)$ & 0.0026 \\
MIA PaCa-2 & $22.51 \pm 2.98\left(P^{*}=0.023\right)$ & $14.98 \pm 1.09\left(P^{*}=0.018\right)$ & 0.0388 \\
MCF-7 & $91.18 \pm 8.99\left(P^{*}=0.011\right)$ & $51.00 \pm 5.20\left(P^{*}=0.041\right)$ & 0.0279 \\
PANC-1 & $34.81 \pm 3.01\left(P^{*}=0.031\right)$ & $27.62 \pm 2.96\left(P^{*}=0.022\right)$ & 0.0281 \\
\hline
\end{tabular}

Data are presented as means \pm SD $(n=3)$.

$P^{*}$ : Significant difference relative to doxorubicin.

$P^{1}$ : Significant difference relative to each other. 


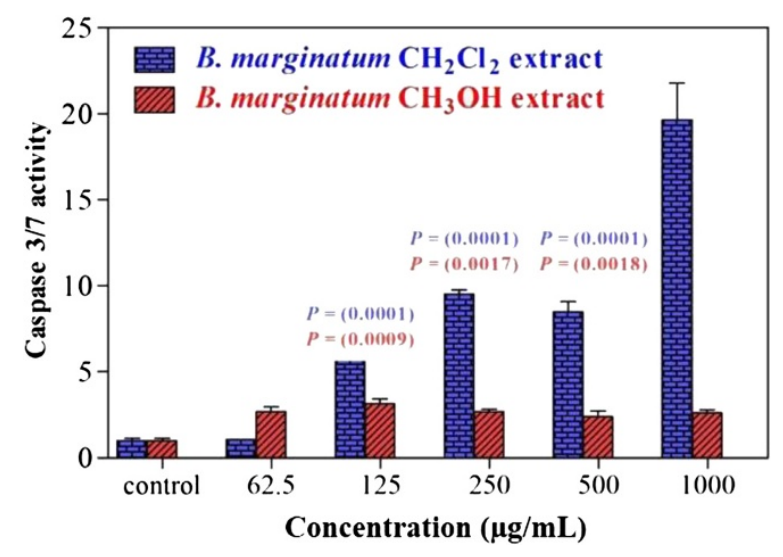

Figure 4 Induction of apoptosis in MIA PaCa-2 cells by B. marginatum extracts. Caspase $3 / 7$ activation was measured after $24 \mathrm{~h}$ of treatment.

\section{Cytotoxicity and apoptosis}

The cytotoxicity of the ME and DCM extracts was evaluated by eight different human cancer cell lines, Caco-2, CCL-81, CCRF-CEM, COS-7, HL-60, MCF-7, MIA $\mathrm{PaCa}-2$, and PANC-1, after $24 \mathrm{~h}$ of incubation. The $\mathrm{IC}_{50}$ values are shown in Table 4 . The cytotoxicity of the ME extract ranged from 22.5 to $576.0 \mu \mathrm{g} / \mathrm{mL}$, while the $\mathrm{DCM}$ extract was more cytotoxic and had $\mathrm{IC}_{50}$ values ranging from 12.5 to $72.8 \mu \mathrm{g} / \mathrm{mL}$. Both CCRF-CEM and MIA PaCa-2 cells were highly sensitive to both extracts, while the green monkey cells were the most resistant cell lines. Caspase 3/7 activity was used to measure the ability of the extracts to initiate the apoptotic cascade. Both extracts activated caspase 3/7. The increase was most apparent with the DCM extract, for which a $1 \mathrm{mg} / \mathrm{mL}$ dose produced 19-fold stimulation (Figure 4). The tested extracts showed higher selectivity for cancer cells when compared with normal hepatocytes. The ME extract had no cytotoxic activity against normal human cells over the range of $1-1000 \mathrm{mg} / \mathrm{mL}$ (unpublished data).

Several other Bupleurum species showed similar cytotoxicity against different cell lines [42-44]. The mechanism of this cytotoxicity was attributed to the saikosaponin content, especially the saponins with an epoxy bridge [42]. Cytotoxicity is mainly mediated through cell cycle arrest in the $G_{2} / M$ phase or inhibition of tubulin polymerization [45]. In addition, induction of apoptosis via the activation of kinases $1 / 2$ and several caspases might be involved [43-45].

Furthermore, quercetin and lignans contributed to the overall cytotoxicity of both extracts. Quercetin blocks signal transduction pathways by inhibiting many kinases, including protein tyrosine kinases and serine/threonine protein kinases, resulting in arrest of the cell cycle at the late $G_{1}$ phase [46] with a proapoptotic activity through activation of KRAS and PI3K [47]. Most lignans, especially those with a structural similarity to podophyllotoxin are known cytotoxic agents [48]. These agents bind to tubulin, leading to inhibition of microtubule formation, and inhibit DNA topoisomerase, thus blocking cell division in the late $\mathrm{G}_{2}$ [49].

The low cytotoxicity of both extracts toward Caco-2 cells compared with the other tested cancer cell lines may arise through the overexpression of multidrugresistance genes, such as MDR1 and MRP1, in this cell line [50,51]. These ATP-dependent efflux transporters facilitated the efflux of xenobiotics from Caco-2 cells, thereby reducing thle internal concentration of cytotoxic drugs and thus their activity [52].

In this work, we investigated the antimicrobial activity of Bupleurum extracts, especially against Gram-positive bacteria such as Streptococcus and Bacillus. Moreover, the antitrypanosomal and antiviral activities of the DCM extract were explored against three different viruses. Further studies of the isolated compounds present in the extracts, particularly lignans, which might serve as lead compounds and could be modified to increase their selectivity were required. However, clinical reports should be collected from patients using these Bupleurum preparations to monitor the efficacy, as well as any side effects or herbal drug interactions.

\section{Conclusions}

In this study, ME and DCM extracts of B. marginatum showed anti-infective and antiproliferative effects.

\section{Competing interests}

The authors declare that they have no competing interests.

\section{Authors' contributions}

MLA and MW designed the study. MLA, MZL, RH, SYE, SHE, EN, FH, MY, AT and DKperformed the experiments. MLA and MW wrote the manuscript. All authors read and approved the final manuscript.

\section{Author details}

${ }^{1}$ Institute of Pharmacy and Molecular Biotechnology, Heidelberg University, Im Neuenheimer Feld 364, 69120 Heidelberg, Germany. 'Department of Pharmacognosy, Faculty of Pharmacy, Ain Shams University, Cairo, Egypt. ${ }^{3}$ Department of Biochemistry, Faculty of Pharmacy, Al-Azhar University, Assiut, Egypt. ${ }^{4}$ Department of Functional Genome Analysis, German Cancer Research Center (DKFZ), Heidelberg, Germany. ${ }^{5}$ Department of Biochemistry and Molecular Biology, Faculty of Pharmacy, Helwan University, Cairo, Egypt.

Received: 10 May 2013 Accepted: 13 January 2014

Published: 17 January 2014

\section{References}

1. Cordell GA: Natural products in drug discovery - Creating a new vision. Phytochem Rev 2002, 1:261-273.

2. Yaniv Z, Bachrach U: Handbook of medicinal plants. New York: Food Products Press : Haworth Medical Press; 2005.

3. Mabberley DJ: Mabberley's plant-book: a portable dictionary of plants, their classification and uses. 3rd edn. Cambridge, UK. New York: Cambridge University Press; 2008.

4. Pan S-L: Bupleurum species: scientific evaluation and clinical applications. Boca Raton: CRC/Taylor \& Francis; 2006.

5. World Health Organization: WHO Monographs on Selected Medicinal Plants Vol 1. Geneva: World Health Organization; 1999. 
6. Ashour ML, Wink M: Genus Bupleurum: a review of its phytochemistry, pharmacology and modes of action. J Pharm Pharmacol 2011, 63:305-321.

7. Wu J-N: An illustrated Chinese materia medica. New York: Oxford University Press; 2005.

8. Fundukian LJ: The Gale encyclopedia of alternative medicine. 3rd edition. Gale, Cengage Learning: Detroit; 2009.

9. Zhou J: Encyclopedia of traditional Chinese medicines vol 1 - molecular structures, pharmacological activities, natural sources and applications. New York: Springer; 2011

10. Huang HQ, Zhang X, Lin M, Shen YH, Yan SK, Zhang WD: Characterization and identification of saikosaponins in crude extracts from three Bupleurum species using LC-ESI-MS. J Sep Sci 2008, 31:3190-3201.

11. Ashour ML, El-Readi MZ, Tahrani A, Eid SY, Wink M: A novel cytotoxic aryltetraline lactone from Bupleurum marginatum (Apiaceae).

Phytochem Lett 2012, 5:387-392.

12. Zhitao L, Minjian Q, Zhengtao W: Study on the constituent $s$ of the roots of Bupleurum Marginatum. J China Pharmaceut Uni 2003, 34:305-308 [In Chinese].

13. Liu Y, Zhang T-T, Zhou J-S, Wang Q: Three new arylnaphthalide lignans from the aerial parts of Bupleurum marginatum WALL. ex DC. Helv Chim Acta 2008, 91:2316-2320.

14. Ashour ML, El-Readi M, Youns M, Mulyaningsih S, Sporer F, Efferth T, Wink M: Chemical composition and biological activity of the essential oil obtained from Bupleurum marginatum (Apiaceae). J Pharm Pharmacol 2009, 61:1079-1087.

15. Hamdan D, El-Readi MZ, Tahrani A, Herrmann F, Kaufmann D, Farrag N, El-Shazly A, Wink M: Chemical composition and biological activity of Citrus jambhiri Lush. Food Chem 2011, 127:394-403.

16. Nibret E, Ashour ML, Rubanza CD, Wink M: Screening of some Tanzanian medicinal plants for their trypanocidal and cytotoxic activities. Phytother Res 2010, 24:945-947.

17. Huber W, Koella JC: A comparison of three methods of estimating EC50 in studies of drug resistance of malaria parasites. Acta Trop 1993, 55:257-261.

18. Nibret E, Sporer F, Asres K, Wink M: Antitrypanosomal and cytotoxic activities of pyrrolizidine alkaloid-producing plants of Ethiopia. J Pharm Pharmacol 2009, 61:801-808.

19. Mulyaningsih S, Sporer F, Reichling J, Wink M: Antibacterial activity of essential oils from Eucalyptus and of selected components against multidrug-resistant bacterial pathogens. Pharm Biol 2011, 49:893-899.

20. Abou-Karam M, Shier WT: A simplified plaque reduction assay for antiviral agents from plants. Demonstration of frequent occurrence of antiviral activity in higher plants. J Nat Prod 1990, 53:340-344.

21. Mosmann T: Rapid colorimetric assay for cellular growth and survival: application to proliferation and cytotoxicity assays. J Immunol Methods 1983, 65:55-63.

22. Reimer TA, Anagnostopoulos I, Erdmann B, Lehmann I, Stein H, Daniel P, Dorken B, Rehm A: Reevaluation of the 22-1-1 antibody and its putative antigen, EBAG9/RCAS1, as a tumor marker. BMC Cancer 2005, 5:47.

23. Tasdemir D, Kaiser M, Brun R, Yardley V, Schmidt TJ, Tosun F, Ruedi P: Antitrypanosomal and antileishmanial activities of flavonoids and their analogues: in vitro, in vivo, structure-activity relationship, and quantitative structure-activity relationship studies. Antimicrob Agents Chemother 2006, 50:1352-1364

24. Wink M: Medicinal plants: source of anti-parasitic secondary metabolites. Molecules 2012, 17:12771-12791.

25. Mamadalieva NZ, Herrmann F, El-Readi MZ, Tahrani A, Hamoud R, Egamberdieva DR, Azimova SS, Wink M: Flavonoids in Scutellaria immaculata and S. ramosissima (Lamiaceae) and their biological activity. J Pharm Pharmacol 2011, 63:1346-1357.

26. Hoet S, Opperdoes F, Brun R, Quetin-Leclercq J: Natural products active against African trypanosomes: a step towards new drugs. Nat Prod Rep 2004, 21:353-364.

27. Gertsch J, Tobler RT, Brun R, Sticher O, Heilmann J: Antifungal, antiprotozoal, cytotoxic and piscicidal properties of Justicidin B and a new arylnaphthalide lignan from Phyllanthus piscatorum. Planta Med 2003, 69:420-424.

28. Wink M: Evolutionary advantage and molecular modes of action of multi-component mixtures used in phytomedicine. Curr Drug Metab 2008, 9:996-1009.
29. Ushio $\mathrm{Y}$, Abe H: Inactivation of measles virus and herpes simplex virus by saikosaponin d. Planta Med 1992, 58:171-173.

30. Chiang LC, Ng LT, Liu LT, Shieh DE, Lin CC: Cytotoxicity and anti-hepatitis $B$ virus activities of saikosaponins from Bupleurum species. Planta Med 2003, 69:705-709.

31. Cheng PW, Chiang LC, Yen MH, Lin CC: Bupleurum kaoi inhibits Coxsackie B virus type 1 infection of CCFS-1 cells by induction of type I interferons expression. Food Chem Toxicol 2007, 45:24-31.

32. Charlton JL: Antiviral activity of lignans. J Nat Prod 1998, 61:1447-1451.

33. Wink M, Van Wyk B-E: Mind-altering and poisonous plants of the world. Portland: Timber Press; 2008.

34. Bedows $E$, Hatfield GM: An investigation of the antiviral activity of Podophyllum peltatum. J Nat Prod 1982, 45:725-729.

35. MacRae WD, Hudson JB, Towers GH: The antiviral action of lignans. Planta Med 1989, 55:531-535.

36. Jassim SA, Naji MA: Novel antiviral agents: a medicinal plant perspective. Appl Microbiol 2003, 95:412-427.

37. Cushnie TP, Lamb AJ: Antimicrobial activity of flavonoids. Int I Antimicrob Agents 2005, 26:343-356.

38. Naithani R, Huma LC, Holland LE, Shukla D, McCormick DL, Mehta RG, Moriarty RM: Antiviral activity of phytochemicals: a comprehensive review. Mini-Rev Med Chem 2008, 8:1106-1133.

39. Kaul TN, Middleton E Jr, Ogra PL: Antiviral effect of flavonoids on human viruses. J Med Virol 1985, 15:71-79.

40. Ohnishi E, Bannai H: Quercetin potentiates TNF-induced antiviral activity. Antiviral Res 1993, 22:327-331.

41. Kim HJ, Woo ER, Shin CG, Park H: A new flavonol glycoside gallate ester from Acer okamotoanum and its inhibitory activity against human immunodeficiency virus-1 (HIV-1) integrase. J Nat Prod 1998, 61:145-148.

42. Hsu YL, Kuo PL, Weng TC, Yen MH, Chiang LC, Lin CC: The antiproliferative activity of saponin-enriched fraction from Bupleurum Kaoi is through Fas-dependent apoptotic pathway in human non-small cell lung cancer A549 cells. Biol Pharm Bull 2004, 27:1112-1115.

43. Cheng YL, Lee SC, Lin SZ, Chang WL, Chen YL, Tsai NM, Liu YC, Tzao C, Yu DS, Harn HJ: Anti-proliferative activity of Bupleurum scrozonerifolium in A549 human lung cancer cells in vitro and in vivo. Cancer Lett 2005, 222:183-193.

44. Fujioka T, Yoshida K, Shibao H, Nagao T, Yoshida M, Matsunaga K, Takata J, Karube Y, Iwase Y, Okabe H, Mihashi K: Antiproliferative constituents from umbelliferae plants. IX. New triterpenoid glycosides from the fruits of Bupleurum rotundifolium. Chem Pharm Bull 2006, 54:1694-1704.

45. Chen YL, Lin SZ, Chang WL, Cheng YL, Harn HJ: Requirement for ERK activation in acetone extract identified from Bupleurum scorzonerifolium induced A549 tumor cell apoptosis and keratin 8 phosphorylation. Life Sci 2005, 76:2409-2420.

46. Csokay B, Prajda N, Weber G, Olah E: Molecular mechanisms in the antiproliferative action of quercetin. Life Sci 1997, 60:2157-2163.

47. Xavier CP, Lima CF, Preto A, Seruca R, Fernandes-Ferreira M, Pereira-Wilson C: Luteolin, quercetin and ursolic acid are potent inhibitors of proliferation and inducers of apoptosis in both KRAS and BRAF mutated human colorectal cancer cells. Cancer Lett 2009, 281:162-170.

48. MacRae WD, Towers GHN: Biological activities of lignans. Phytochemistry 1984, 23:1207-1220.

49. Wink M: Plant secondary metabolism: diversity, function and its evolution. Nat Prod Commun 2008, 3:1205-1216

50. Seithel A, Karlsson J, Hilgendorf C, Bjorquist A, Ungell AL: Variability in mRNA expression of ABC- and SLC-transporters in human intestinal cells: comparison between human segments and Caco-2 cells. Eur J Pharm Sci 2006, 28:291-299.

51. Wink M, Ashour ML, El-Readi MZ: Secondary metabolites from plants inhibiting $A B C$ transporters and reversing resistance of cancer cells and microbes to cytotoxic and antimicrobial agents. Front Microbiol 2012, 3:130.

52. El-Readi MZ, Hamdan D, Farrag N, El-Shazly A, Wink M: Inhibition of P-glycoprotein activity by limonin and other secondary metabolites from Citrus species in human colon and leukaemia cell lines. Eur J Pharmacol 2010, 626:139-145.

doi:10.1186/1749-8546-9-4

Cite this article as: Ashour et al:: Anti-infective and cytotoxic properties of Bupleurum marginatum. Chinese Medicine 2014 9:4. 